\title{
ВПЛИВ АНТИБІОТИКОТЕРАПІЇ НА МІКРОФЛОРУ РІЗНИХ БІОТОПІВ У ПАЦІЄНТІВ, ХВОРИХ НА ЦУКРОВИЙ ДІАБЕТ
}

\author{
○С. І. Климнюк, В. Б. Ясній, О. Р. Ясній
}

Тернопільський національний медичний університет імені І. Я. Горбачевського МОЗ України

РЕЗЮМЕ. За даними ВООЗ, антибіотикорезистентність $€$ однією з десяти найбільших загроз для здоров'я, з якими стикається людство.

Мета - проаналізувати літературні джерела останніх років щодо поширеності антибіотикорезистентності у хворих на цукровий діабет (ЦД) з різними інфекційними ускладненнями.

Матеріал і методи. Проаналізовано публікації зі вказаної проблеми в провідних міжнародних медичних і мікробіологічних часописах, а також інтернет-ресурсах.

Результати. Зловживання та надмірне застосування антибактеріальних препаратів - основні причини розвитку стійкості збудників. У значній мірі це стосується хворих на ЦД, оскільки вони мають велику кількість супутніх патологій та багато хронічних ускладнень і часто потребують застосування антибіотиків, що спричиняє антибіотикорезистентність. Виявлено, що у хворих на ЦД $є$ певні особливості мікрофлори при захворюванні дихальних шляхів, шкіри, сечостатевої системи, ротової порожнини. Показана висока резистентність мікроорганізмів до антибактеріальних препаратів, що знижує ефективність лікування. Зазначається, що у пацієнтів з ЦД 2-го типу значно зростає ризик виникнення інфекцій сечостатевих шляхів. Показано, що $E$. coli найпоширеніший уропатоген пацієнтів з ЦД, за яким слідують коагулазонегативні стафілококи. Всі виділені бактерії були стійкими до ампіциліну, але чутливими до нітрофурантоїну. Грамнегативні ізоляти показали високий рівень стійкості до триметоприм-сульфаметоксазолу в 81,8 \%, гентаміцину - у 72,7 \% та цефтріаксону в 63,6 \% пацієнтів. Грампозитивні бактерії мали резистентність до пеніциліну у 87,5 \%, норфлоксацину - у 62,5 \% та ципрофлоксацину у 50,0\% пацієнтів.

Висновок. Антибіотикотерапія у хворих на ЦД повинна проводитися з обов' язковим урахуванням чутливості збудника. Глибше розуміння відповіді мікробіоценозу на дію антибіотиків сформує нові підходи до лікування хворих на ЦД.

КлючОВІ СлОВА: цукровий діабет; антибіотикорезистентність; антибіотики; мікробіоценоз.

Вступ. За даними ВООЗ, антибіотикорезистентість $є$ однією з десяти найбільших загроз для здоров'я, з якими стикається людство. Зловживання та надмірне застосування антибіотиків основні причини розвитку стійкості збудників. у значній мірі це стосується хворих на цукровий діабет (ЦД), оскільки вони мають велику кількість супутніх патологій та багато хронічних ускладнень і часто потребують застосування антибіотиків, що спричиняє антибіотикорезистентність [1].

Мета - проаналізувати літературні джерела останніх років для з'ясування поширеності антибіотикорезистентності у хворих на ЦД із різними інфекційними ускладненнями.

Матеріал і методи дослідження. Актуальну інформацію про поширення антибіотикорезистентності в багатьох країнах світу, а також тенденції до застосування антибіотиків різних груп у зручній візуальній інтерактивній формі представлено в доступному Інтернет-ресурсі [2]. Основними джерелами інформації $\epsilon$ державні та приватні лабораторні мережі, які регулярно збирають дані аналізів щодо стійкості до антибактеріальних препаратів. Результати представлено для 75 країн за період з 1999 по 2017 рр. і вони постійно оновлюються. У звіти включено дані стосовно 12 мікроорганізмів та 17 основних класів антибіотиків.
Результати й обговорення. Бактеріальні, грибкові та вірусні інфекції - найпоширеніші етіологічні чинники інфекції дихальних шляхів у пацієнтів з ЦД [3]. Типи організмів, які відповідають за розвиток пневмонії у хворих на ЦД, відрізняються від інших осіб. При ЦД переважають грамнегативні бактерії, такі як K. pneumoniae ma S. aureus. Найважливішими збудниками інфекцій дихальних шляхів у діабетиків $\epsilon$ S. pneumoniae та вірус грипу [4]. Протягом перших чотирьох днів госпіталізації найпоширенішими бактеріями, які викликають госпітальну пневмонію, $\in$ S. pneumoniae, Enterobacter, K. pneumoniae, E. coli, Serratia, S. aureus (чутливий до метициліну), Proteus та Haemophilus influenzae. 3 п'ятого дня госпіталізації переважають бактерії Acinetobacter spp., Staphylococcus aureus (метицилін-стійкий), E. coli, L. pneumophila, Pseudomonas aeruginosa та K. pneumoniae [5]. У дослідженнях антибактеріальної резистентності при пневмонії у пацієнтів з ЦД виявлено, що Klebsiella pneumoniae показала стійкість до фосфоміцину (26,7 \% проти $37,6 \%)$ та сульфаметоксазолу (22,7 \% проти $32,5 \%$ ). У реанімаційних пацієнтів із цукровим діабетом виявлено значно нижчі показники резистентності K. Pneumoniae до фосфоміцину, азтреонаму, тобраміцину, меропенему, амікацину та цефотетану, порівняно з пацієнтами без діабету. 
Огляди літератури, оригінальні дослідження, погляд на проблему, випадок з практики, короткі повідомлення

Пацієнти з вищим рівнем глікованого гемоглобіну (НbA1c) показали значно нижчу стійкість до сульперазону (11,7 \% проти 40,0 \%) та фосфоміцину (14,3\% проти 66,7 \%), порівняно з хворими, у яких $\mathrm{HbA} 1 \mathrm{c}<6,5 \%[6]$.

Діабетичний остеомієліт стопи розвивається приблизно у 44-68 \% пацієнтів, які потрапили до лікарні з діабетичною інфекцією стопи, і стає причиною ампутації у таких хворих [7]. Із ран пацієнтів із ЦД було виділено 63 штами мультиантибіотикорезистентних (MAP) бактерій: Staphylococcus aureus, Enterococcus i Pseudomonas. Із 52 ізолятів S. aureus 30 були MAP, а 26 - стійкими принаймні до одного класу антибіотиків. Із 44 ізолятів ентерококів 18 складали МАР, із яких 8 стійкі до ванкоміцину. 339 отриманих ізолятів псевдомонади 12 були MAP [8]. При обстеженні інфікованих ран стопи 105 пацієнтів встановлено, що поширеність мікробів родини Enterobacteriaceae складала 51,5 \%. Грамнегативні мікроби виділено у 60 \% культур, а грампозитивні коки, такі як Staphylococcus aureusу $20 \%$, Enterococcus faecalis - у 17,9 \%. Щодо показників стійкості до антибіотиків виявлено, що Staphylococcus aureus стійкий до метициліну (63,0 \%) та ципрофлоксацину (55,5 \%), крім того, 43,5 \% грамнегативних ізольованих мікробів стійкі до ципрофлоксацину [9].

Установлено, що у пацієнтів з ЦД 2-го типу значно зростає ризик виникнення інфекцій сечостатевих шляхів [10]. Досліджено, що E. coli- найпоширеніший уропатоген пацієнтів із ЦД, за яким слідують коагулазонегативні стафілококи. Всі виділені бактерії були стійкими до ампіциліну, але чутливими до нітрофурантоїну. Грамнегативні ізоляти показали високий рівень стійкості до триметоприм-сульфаметоксазолу у 81,8 \%, гентаміцину - у 72,7 \% та цефтріаксону у 63,6 \% пацієнтів. Грампозитивні бактерії мали резистентність до пеніциліну в 87,5 \%, норфлоксацину - в 62,5 \% та ципрофлоксацину в 50,0 \% пацієнтів. МАР спостерігалась у 93,9 \% випадках. Висока стійкість до триметоприм-сульфаметоксазолу, антибіотика першої лінії, викликає велике занепокоєння у лікарів [11].

У дослідженні аеробної мікробної флори у ротовій порожнині 154 осіб із ЦД та 111 осіб без
ЦД у віці від 18 років виявлено тринадцять різних родів аеробних мікроорганізмів [12]. Найпоширенішими є мікроби - Streptococcus spp. (99,6 \%), Candida albicans (17,0 \%), Serratia spp. (7,2 \%), інші Candida spp. (6,8 \%), коагулазонегативні стафілококи (6,4 \%) і Klebsiella spp. (5,7 \%)). Серед особливостей мікробного пейзажу лОР органів у хворих на цукровий діабет виділяють переважання умовно-патогенної і транзиторної мікрофлори, а в осередках запалення - цукролітичної мікрофлори і неферментуючих бактерій (псевдомонади). У ротоглотці хворих на ЦД у більшості випадків виявлено а-гемолітичні стрептококи (58 \%), які є представниками нормальної мікрофлори глотки, а також ү-гемолітичні стрептококи (9\%) і Neisseria spp. (5\%). У 18 \% пацієнтів із ЦД виявлено гриби роду Candida і Aspergillus. Staphylococcus aureus траплявся у $10 \%$ спостережень. У переважній більшості випадків (98 \%) мікроорганізми представлено у складі асоціацій. При оцінці характеру дії антибіотиків резистентність мікрофлори, виділеної від хворих на ЦД, була вищою. Найбільшу чутливість виділених штамів виявлено до антибактеріальних препаратів групи сучасних макролідів, фторхінолонів, а також цефалоспоринів III-IV поколінь [13].

Антибіотикотерапія повинна бути специфічна для культури збудника, оскільки це забезпечує вищий рівень успішності лікування, порівняно $з$ емпіричною терапією. Краще розуміння відношення мікробіоценозу до дії антибіотиків дасть нові уявлення про перенаправлення терапії та може покращити клінічні результати в майбутньому [14].

Висновки. Встановлено, що у хворих на ЦД $є$ певні особливості мікрофлори при захворюванні дихальних шляхів, шкіри, сечостатевої системи, ротової порожнини та ротоглотки. Показана висока резистентність мікроорганізмів до антибактеріальних препаратів, що знижує ефективність лікування. Антибіотикотерапія у пацієнтів із ЦД має проводитися з обов'язковим урахуванням чутливості збудника.

Перспективи подальших досліджень. Глибше розуміння відповіді мікробіоценозу на дію антибіотиків сформує нові підходи до лікування хворих на ЦД.

\section{ЛITEPATУРA}

1. Antibiotic resistance [Electronic resource]. 2020. - URL: https://www.who.int/news-room/factsheets/detail/antibiotic-resistance (accessed: 14.02.2021).

2. ResistanceMap - About [Electronic resource]. URL: https://resistancemap.cddep.org/About.php (accessed: 14.02.2021).
3. Alves $C$. Infections in patients with diabetes mellitus: A review of pathogenesis / C. Alves, J. Casqueiro, J. Casqueiro // Indian J. Endocrinol. Metab. -2012. - Vol. 16 (Suppl. 1). - P. 27-36.

4. Importance of legionella pneumophila in the etiology of severe community-acquired pneumonia in santia- 
Огляди літератури, оригінальні дослідження, погляд на проблему, випадок з практики, короткі повідомлення go, chile / F. Arancibia, C. P. Cortes, M. Valdés [et al.] // Chest. - 2014. - Vol. 145 (2). - P. 290-296.

5. Klekotka R. B. The etiology of lower respiratory tract infections in people with diabetes / R. B. Klekotka, E. Mizgała, W. Król // Pneumonol. Alergol. Pol. - 2015. Vol. 83 (5). - P. 401-408.

6. Diabetes-associated infections: development of antimicrobial resistance and possible treatment strategies / M. S. H. Akash, K. Rehman, F. Fiayyaz [et al.] // Arch. Microbiol. - 2020. - Vol. 202 (5). - P. 953-965.

7. The microbiome of diabetic foot osteomyelitis / S. A. V. van Asten, J. La Fontaine, E. J. G. Peters [et al.] // Eur. J. Clin. Microbiol. Infect. Dis. - 2016. - Vol. 35 (2). P. 293-298.

8. Prevalence of Multiple Antibiotic Resistant Infections in Diabetic versus Nondiabetic Wounds / U. Trivedi, S. Parameswaran, A. Armstrong [et al.] // J. Pathog. 2014. - Vol. 2014. - P. 173053.

9. Microbiologic characteristics and antibiotic resistance rates of diabetic foot infections / D. G. Pontes, I. T. D. C. E. Silva, J. J. Fernandes [et al.] // Rev. Col. Bras. Cir. - 2020. - Vol. 47. - P. e2020-2471.

10. Risk characterization for urinary tract infections in subjects with newly diagnosed type 2 diabetes / A. Z. Fu, K. Iglay, Y. Qiu [et al.] // J. Diabetes Complications. - 2014. Vol. 28 (6). - P. 805-810.

11. Nigussie D. Prevalence of uropathogen and their antibiotic resistance pattern among diabetic patients / D. Nigussie, A. Amsalu // Turk. J. Urol. - 2017. - Vol. 43 (1). P. 85-92.

12. Microbiological profile of oral infections in diabetic patients and non-diabetic controls in southwest, cameroon / M. E. A. Bissong, P. N. Fon, F. H. L. Kamga, T. N. Akenji // African J. Clin. Exp. Microbiol. - 2014. Vol. 15 (3). - P. 138-143.

13. Гуров А. В. Особенности микробного пейзажа и проблемы антибактериальной терапии воспалительных заболеваний лОР-органов у больных сахарным диабетом / А. В. Гуров, М.А.Юшкина // Вестник отоларингологии. - 2018. - Vol. 1. - P. 59-61.

14. Lázaro-Martínez J. L. Antibiotics versus conservative surgery for treating diabetic foot osteomyelitis: A randomized comparative trial / J. L. Lázaro-Martínez, J. AragónSánchez, E. García-Morales // Diabetes Care. - 2014. Vol. 37 (3). - P. 789-795.

\section{REFERENCES}

1. (2020). Antibiotic resistance. www.who.int. Retrieved from: https:// /news-room/fact-sheets/detail/ antibiotic-resistance

2. (2021). ResistanceMap - About. resistancemap. cddep.org. Retrieved from: https://resistancemap.cddep. org/Abot.php

3. Alves, C., Casqueiro, J., \& Casqueiro, J. (2012). Infections in patients with diabetes mellitus: A review of pathogenesis. Indian J. Endocrinol. Metab., 16, 1, 27-36. DOI: https://doi.org/10.4103/2230-8210.94253

4. Arancibia, F., Cortes, C.P., Valdés, M., Cerda, J., Hernández, A., Soto, L., \& Torres, A. (2014). Importance of legionella pneumophila in the etiology of severe communityacquired pneumonia in santiago, chile. Chest, 145 (2), 290296. DOI: https://doi.org/10.1378/chest.13-0162

5. Klekotka, R.B., Mizgała, E., \& Król, W. (2015). The etiology of lower respiratory tract infections in people with diabetes. Pneumonol. Alergol. Pol., 83 (5), 401-408. DOI: https://doi.org/10.5603/PiAP.2015.0065

6. Akash, M.S.H., Rehman, K., Fiayyaz, F., Sabir, S., \& Khurshid, M. (2020). Diabetes-associated infections: development of antimicrobial resistance and possible treatment strategies. Arch. Microbiol., 202 (5), 953-965. DOI: https://doi.org/10.1007/s00203-020-01818-x

7. Asten, S.A.V., La Fontaine, J., Peters, E.J.G., Bhavan, K., Kim, P.J., \& Lavery, L.A. (2016). The microbiome of diabetic foot osteomyelitis. Eur. J. Clin. Microbiol. Infect. Dis., 35 (2), 293-298. DOI: https://doi.org/10.1007/s10096-015-2544-1

8. Trivedi, U., Parameswaran, S., Armstrong, A., Burgueno-Vega, D., Griswold, J., Dissanaike, S., \& Rumbaugh, K.P. (2014). Prevalence of multiple antibiotic resistant infections in diabetic versus nondiabetic wounds. J. Pathog., 2014, 173053. DOI: https://doi.org/10.1155/2014/173053

9. Pontes, D.G., Silva, I.T.D.C.E., Fernandes, J.J., Monteiro, A.F.G., Gomes, P.H.D.S., Ferreira, M.G.M., \& Cavalcante. L.P. (2020). Microbiologic characteristics and antibiotic resistance rates of diabetic foot infections. Rev. Col. Bras. Cir., 47, e2020-2471. DOI: https://doi.org/10.1590/01006991e-20202471

10. Fu, A.Z., Iglay, K., Qiu, Y., Engel, S., Shankar, R., \& Brodovicz, K. (2014). Risk characterization for urinary tract infections in subjects with newly diagnosed type 2 diabetes. J. Diabetes Complications, 28 (6), 805-810. DOI: https://doi.org/10.1016/j.jdiacomp.2014.06.009

11. Nigussie, D., \& Amsalu, A. (2017). Prevalence of uropathogen and their antibiotic resistance pattern among diabetic patients. Turk. J. Urol., 43 (1), 85-92. DOI: https://doi.org/10.5152/tud.2016.86155

12. Bissong, M., Fon, P., Kamga, F., \& Akenji, T. (2014). Microbiological profile of oral infections in diabetic patients and non-diabetic controls in southwest, cameroon. African J. Clin. Exp. Microbiol., 15 (3), 138. DOI: https://doi.org/10.4314/ajcem.v15i3.4

13. Gurov, A.V., \& Yushkina, M.A. (2010). Osobennosty mykrobnoho peyzazha i problemy antybakteryalnoy terapyy vospalytelnykh zabolevanyy LOR-orhanov u bolnykh sakharnym dyabetom [The peculiar features of the microbial paysage and the problems of antibacterial therapy of the inflammatory ENT diseases in the patients presenting with diabetes mellitus]. Vestnik otolarynholohyyOtolaryngology Bulletin, 1, 59-61 [in Russian].

14. Lázaro-Martínez, J.L., Aragón-Sánchez, J., \& García-Morales, E. (2014). Antibiotics versus conservative surgery for treating diabetic foot osteomyelitis: A randomized comparative trial. Diabetes Care, 37 (3), 789-795. DOI: https://doi.org/10.2337/dc13-1526 
Огляди літератури, оригінальні дослідження, погляд на проблему, випадок з практики, короткі повідомлення

\title{
ВЛИЯНИЕ АНТИБИОТИКОТЕРАПИИ НА МИКРОФЛОРУ РАЗНЫХ БИОТОПОВ У ПАЦИЕНТОВ, БОЛЬНЫХ САХАРНЫМ ДИАБЕТОМ
}

\author{
ФС. И. КлимнюК, В. Б. Ясний, О. Р. Ясний
}

Тернопольский национальный медицинский университет имени И. Я. Горбачевского МОз Украины

РЕЗЮМЕ. По данным ВОЗ, антибиотикорезистентность является одной из десяти крупнейших угроз здоровью, с которыми сталкивается человечество.

Цель - проанализировать литературные источники последних лет относительно распространенности антибиотикорезистентности у больных сахарным диабетом (СД) с различными инфекционными осложнениями.

Материал и методы. Проанализированы публикации по указанной проблеме в ведущих международных медицинских и микробиологических журналах, а также Интернет-ресурсах.

Результаты. Злоупотребления и чрезмерное применение антибактериальных препаратов - основные причины развития устойчивости возбудителей. В значительной степени это касается больных СД, поскольку они имеют большое количество сопутствующих патологий и много хронических осложнений и часто требуют применения антибиотиков, что вызывает антибиотикорезистентность. Выявлено, что у больных СД есть определенные особенности микрофлоры при заболеваниях дыхательных путей, кожи, мочеполовой системы, ротовой полости. Показана высокая резистентность микроорганизмов к антибактериальным препаратам, снижающим эффективность лечения. Отмечается, что у пациентов с СД 2-го типа значительно возрастает риск возникновения инфекций мочеполовых путей. Показано, что $E$. coli- распространенный уропатоген у пациентов с СД, за которым следуют коагулазо-негативные стафилококки. Все выделенные бактерии были устойчивыми к ампициллину, но чувствительными к нитрофурантоину. Грамотрицательные изоляты показали высокий уровень устойчивости к триметоприм-сульфаметоксазолу у 81,8 \%, гентамицину - у 72,7 \% и цефтриаксону у 63,6 \% пациентов. Грамположительные бактерии имели резистентность к пенициллину у 87,5 \%, норфлоксацину - у 62,5 \% и ципрофлоксацину у $50,0 \%$ пациентов.

Вывод. Антибиотикотерапия у больных СД должна проводиться с обязательным учетом чувствительности возбудителя. Глубокое понимание ответа микробиоценоза на действие антибиотиков сформирует новые подходы к лечению больных СД.

КЛЮЧЕВЫЕ СЛОВА: сахарный диабет; антибиотикорезистентность; антибиотики; микробиоценоз.

\section{THE EFFECT OF ANTIBIOTIC THERAPY ON THE MICROBIOME OF VARIOUS BIOTOPES IN THE PATIENTS WITH DIABETES MELLITUS}

\author{
OS. I. Klymnyuk, V. B. Yasnii, O. R. Yasnii \\ I. Horbachevsky Ternopil National Medical University
}

SUMMARY. According to WHO, antibiotic resistance is one of the 10 greatest health threats facing humanity.

The aim - is to analyze the literature sources of recent years on the prevalence of antibiotic resistance in patients with diabetes mellitus (DM) with various infectious complications.

Material and Methods. There were analyzed the studies of this disease, that were published in leading international medical and microbiological journals, as well as Internet resources.

Results. Abuse and overuse of antibacterial drugs are the main reasons for the development of resistance to pathogens. This is especially true for people with diabetes, as they have a large number of comorbidities, as well as many chronic complications and often require the use of antibiotics, which causes antibiotic resistance. It was found that patients with diabetes have certain traits of the microflora during diseases of the respiratory tract, skin, genitourinary system, oral cavity. There was shown high resistance of microorganisms to antibacterial drugs, which reduces the effectiveness of treatment. It was noted that the patients with type 2 diabetes significantly increase the risk of genitourinary tract infections. $E$. coli has been shown to be the most common uropathogen in patients with diabetes, followed by coagulase-negative staphylococci. All isolated bacteria were resistant to ampicillin but sensitive to nitrofurantoin. Gramnegative isolates showed a high level of resistance to trimethoprim-sulfamethoxazole in $81.8 \%$, gentamicin in $72.7 \%$ and ceftriaxone in $63.6 \%$ of patients. Gram-positive bacteria showed resistance to penicillin in $87.5 \%$, norfloxacin in $62.5 \%$ and ciprofloxacin in $50.0 \%$ of patients.

Conclusions. Therefore, the antibiotic therapy in patients with diabetes should be carried out with regard to the sensitivity of the pathogen. A deeper understanding of the response of the microbiocenosis on the action of antibiotics will form new approaches to the treatment of patients with diabetes.

KEY WORDS: diabetes mellitus; antibiotic resistance; antibiotics; microbiocenosis. 